\title{
The significance of a-defensins 1-3 in Behcet's disease: a case-control study among Egyptian patients
}

\author{
Reham M. Shaat ${ }^{*}$, Samah El Meadawy ${ }^{2}$, Ehsan Mohamed Rizk ${ }^{3}$, Mohamed Sherif Abd Elgawad ${ }^{4}$ and \\ Tamer O. Elsaid ${ }^{1}$
}

\begin{abstract}
Background: Behcet's disease (BD) is associated with uveitis, oral ulcers, genital ulcers and arthritis. Enhanced activity of innate immunity components, such as neutrophils, natural killer (NK) cells and endothelial cells, is a prominent feature of BD. The aim of this study was to clarify the significance of a-defensins 1-3 in BD and detect their correlation with disease activity, severity and oral ulcer activity.

Results: Significant differences were found between Behcet's patients and controls as regards serum a-defensins 1-3 (median 10.1, IQR 4-45 $\mu \mathrm{g} / \mathrm{ml}$ versus median 7.4, IQR 0.6-13.2 $\mu \mathrm{g} / \mathrm{ml}, p=0.001$ ) and salivary a-defensins 1-3 (median 17.4, IQR 5.7-44 $\mu \mathrm{g} / \mathrm{ml}$ versus median 8.6, IQR $3.3-11 \mu \mathrm{g} / \mathrm{ml}, p<0.001$ ). Receiver operating characteristic (ROC) showed a fair area under curve (AUC) (AUC $=0.743$ ), with sensitivity of $40 \%$ and specificity $100 \%$ at cutoff value of $17.3 \mu \mathrm{g} / \mathrm{ml}$ for serum a-defensins 1-3, while salivary a-defensins 1-3 showed excellent AUC (AUC = 0.936), with sensitivity of 93.3\% and specificity of $86.7 \%$ at cutoff value of $9.8 \mu \mathrm{g} / \mathrm{ml}$. The levels of serum and salivary a-defensins $1-3>$ cutoff value were significantly higher in active severe Behcet's patients with active oral ulcers $(p<0.001)$.
\end{abstract}

Conclusion: a-Defensins 1-3 may be involved in the pathogenesis of $\mathrm{BD}$ and could be valuable markers in the determination of disease activity, severity and oral ulcer activity.

Keywords: Behcet's disease, Salivary a-defensins 1-3, Serum a-defensins 1-3, Innate immunity, Oral ulcers, IL6

\section{Key points}

- $\alpha$-Defensins 1-3 are involved in the pathogenesis of BD.

- $\alpha$-Defensins 1-3 are valuable markers of Behcet's disease activity.

\section{Background}

Behcet's disease (BD) is a systemic chronic disease characterised by oral ulcers, vasculitis, arthritis, genital ulcers and uveitis. It is more common in Turkey, China, Korea and Japan [1].

\footnotetext{
*Correspondence: reham1975@yahoo.com; rehamshaat@gmail.com; rehamshaat@mans.edu.eg

${ }^{1}$ Rheumatology and Rehabilitation Department, Faculty of Medicine, Mansoura University, El Gomhoria street, Mansoura, Egypt

Full list of author information is available at the end of the article
}

The innate immune system is suggested to participate in the pathogenesis of $\mathrm{BD}$, as manifested by the expression of toll-like receptor expression in affected cells, increased mucocutaneous symptoms and neutrophil hyper-reactivity to streptococci or heat shock proteins [2]. It was found that BD neutrophils are more active and express more adhesion molecules than in healthy controls [3].

Defensins include three subfamilies $\alpha$-, $\beta$ - and $\gamma$-defensins. Neutrophils are generous in $\alpha$-defensins that are liberated extracellularily during inflammation, leading to cell adhesion stimulation, chemokine liberation, reactive oxygen species overexpression and $\mathrm{T}$ cell chemotaxis [4].

Initially, human alpha defensin peptides were found in neutrophils and are named human neutrophil peptides [5].

Human neutrophilic peptides 1-3 are encoded by two genes DEFA1 and DEFA3 found at chromosome 8, site

\section{Springer Open}

(0) The Author(s). 2020 Open Access This article is licensed under a Creative Commons Attribution 4.0 International License, which permits use, sharing, adaptation, distribution and reproduction in any medium or format, as long as you give appropriate credit to the original author(s) and the source, provide a link to the Creative Commons licence, and indicate if changes were made. The images or other third party material in this article are included in the article's Creative Commons licence, unless indicated otherwise in a credit line to the material. If material is not included in the article's Creative Commons licence and your intended use is not permitted by statutory regulation or exceeds the permitted use, you will need to obtain permission directly from the copyright holder. To view a copy of this licence, visit http://creativecommons.org/licenses/by/4.0/. 
8p23.1. DEFA1 and DEFA3 encode similar peptides the difference in the first amino acid from alanine in HNP-1 to aspartic acid in HNP-3; HNP-2 is an N-terminally truncated iso-form without the first amino acid [6].

Defensins initially attracted interest due to their potent antimicrobial functions and highly conserved structure. Consequently, several immunomodulatory functions like chemotactic effects and the ability to induce the production of cytokines have been identified, suggesting that these peptides connect innate and adaptive immune responses [7]. Their importance for autoimmune disorders is supported by the recent finding of modulated defensin expression in patients with systemic lupus erythematosus [8].

Interestingly, high $\alpha$-defensin levels have been reported in the bronchoalveolar lavage fluid and plasma of one Wegener's granulomatosis (WG) patient previously [9] and furthermore in other vasculitic diseases, like microscopic polyangiitis [10] and cutaneous vasculitis [11].

Defensins have a great role in the control of inflammatory and immunologic processes like complement activation, cytotoxicity, chemotaxis of immature dendritic cell, CD4+/CD45RA+ naïve T cell, CD8+ T cells and monocytes, cytokine induction and enhancement of humoral and cellular response [12]. Several studies found that one of the genes of chromosome 8 perhaps could be involved in the pathogenesis of $\mathrm{BD}$ [13].

Alpha defensins might be among the main effector molecules in BD lesions. Neutrophils and NK cells that invade the site of inflammation and secrete defensins in harmful amounts in response to stress signals may be involved in the pathogenesis of the disease. The examined skin biopsies from the forearm especially in the corium after pathergy reactions reveal an increase in neutrophils rich in HNP 1-3 [14].

$\mathrm{BD}$ is a disorder with oral tissue inflammation leading to ulcer development; the first line of defences with neutrophils can be expected to be enhanced in patients with BD. Various functions of neutrophils such as chemotaxis, phagocytosis and oxidative burst responses are increased in patients with $\mathrm{BD}$, and over-reactive neutrophils have been suggested to participate to tissue damage [15].

As there is no universally recognised pathognomonic laboratory marker of BD [16], this study aimed to clarify the significance of serum as well as salivary $\alpha$-defensins 1-3 in BD and their relation to disease activity and severity among Egyptian patients.

\section{Methods}

\section{Study participants}

This is a case-control study in a cohort of Egyptian patients and included 60 patients with $\mathrm{BD}$ with age ranging from 30 to 45 years who were diagnosed according to the international diagnostic criteria of BD [17]. Patients were recruited from the outpatient clinics of Rehabilitation,
Rheumatology, and Internal Medicine, Mansoura University Hospital. They were compared to 60 age- and sexmatched healthy controls. A written informed consent was taken from all participants before the beginning of the study. The study was approved by the Institutional Research Board Mansoura University Faculty of Medicine code (R/16.03.118).

\section{Exclusion criteria}

- Oral mucosal disorders not caused by BD: ex. Pemphigus vulgaris, mucous membrane pemphigoid, lichen plans and erythema multiform

- Autoimmune diseases such as rheumatoid arthritis, systemic lupus erythematosus and spondyloarthropathies

- Cancer

- Infection

\section{Data collection and clinical examination}

Demographic and clinical data were taken from all patients including age, sex, disease duration, systemic clinical signs and symptoms, full musculoskeletal examination and intraoral examination.

\section{Evaluation of BD}

Disease activity was assessed by Behcet's Syndrome Activity Score (BSAS) [18]. BSAS has 10 questions, which consists of visual analogue scales for patient's level of discomfort with regard to oral ulcers, genital ulcers, skin lesions and current disease activity along with the number of oral ulcers, genital ulcers and skin lesions present, and records symptoms attributable to the gastrointestinal, vascular or eye involvement. The VAS questions are all scored $0-10$, and the remaining are scored categorically, 0, 5 or 10 depending on the response, for a total score of 0-100; patients complete the BSAS at the time of the visit to the treating doctor, with no input from the physician.

Disease severity was estimated following Krause et al. study [19].

Severity score will be calculated as the sum of 1 point for each mild manifestation, 2 points for each moderate manifestation and 3 points for each severe manifestation.

\section{Mild}

Oral aphthosis, genital ulcer, typical skin lesions, arthralgia, recurrent headache, mild gastrointestinal symptoms, epididymitis, pleuritic pain, superficial vein thrombosis

\section{Moderate}

Arthritis, deep venous thrombosis of the legs, anterior uveitis, gastrointestinal bleeding 


\section{Severe}

Posterior/panuveitis, retinal vasculitis, arterial thrombosis or major vein (vena cava, hepatic) thrombosis, aneurysms, neuro-Behçet, bowel perforation

Oral ulcer activity was estimated by Mumcu composite index [20]. Mumcu et al. proposed a composite index to monitor the clinical manifestations associated with oral ulceration in BD patients.

This index evaluates the activity of the oral ulcer, ulcer pain and functional disability.

$>$ Oral ulceration activity is recorded as the number of ulcers in the past 30 days. This is scored 0 point if there were no ulcers and scored 1 point for the presence of oral ulcers in the previous month.

$\triangleright$ Pain was evaluated by $100-\mathrm{mm}$ visual analogue scale (VAS; 0, no pain, to 100, severe pain) by patients. Then, the VAS score was categorised to calculate the score as follows: $\leq 10$ : $0 ; 11-20$ : 1; 21-40: 2 ; 41-60: 3; 61-80: 4; and 81 and over: 5 points.

$\triangleright$ Functional status (the effect of oral ulcer on tasting, talking, eating, chewing and swallowing) was evaluated by a 5-point Likert-type scale:

- None of the time (0 points)

- Little of the time (1 point)

- Some of the time (2 points)

- Most of the time (3 points)

- All of the time (4 points)

\section{Laboratory assessment}

Serum and salivary samples were obtained from both patients and controls. Samples of unstimulated whole saliva were obtained during $15 \mathrm{~min}$ in the morning due to the circadian rhythm of saliva secretion. Salivary and serum $\alpha$-defensins 1-3 were assayed using $\alpha$-defensins 13 ELISA kit (PELOBIOTECH GmbH-Am Klopferspitz 19-82152 Planegg, Germany). IL-6 was assayed using ELISA Kit (Elabscience, Bethesda, MD, USA). Erythrocyte sedimentation rate (ESR), neutrophil count and Creactive protein were measured.

\section{Statistical analysis}

The collected data were revised, coded, tabulated and introduced to a PC using Statistical Package for Social Science (SPSS 20 for windows; SPSS Inc, Chicago, IL, 2011). The Student $T$ test was taken to assess the statistical significance of the difference between two study groups means. The Mann-Whitney test ( $U$ test) was taken to assess the statistical significance of the difference of a non-parametric variable between two study groups. Differences were significant at the level $p \leq 0.05$.

\section{Results}

The present study comprised 60 patients with Behcet's disease. They were 38 males and 22 females and their mean age was $36.16 \pm 8.05$ compared to 60 healthy controls, who were 32 males and 28 females and have a mean age of $34.46 \pm 6.18$. No statistically significant difference was found between both groups as regards age and sex $(p=0.09,0.35)$.

In Behcet's patients, oral ulcers were the most common clinical manifestation (70\%) followed by arthralgia (60\%), posterior uveitis (40\%), genital ulcers (26.7\%), deep venous thrombosis (DVT) (20\%), anterior and panuveitis $(16.7 \%)$, arthritis and neurological manifestations (6.7\%). The severity score was median 14.5 , IQR 6-25; the activity score was median 27.5, IQR 12-55); and the oral ulcer activity score was median 4. 5, IQR $0-9$.

There were significant differences between Behcet's patients and the control group as regards ESR 1st h (median 28, IQR 4-76 mm/h versus median 10, IQR 5-30 $\mathrm{mm} / \mathrm{h}, p<0.001$ ), ESR 2nd h (median 45, IQR 4-112 $\mathrm{mm} / \mathrm{h}$ versus median 10 , IQR $5-30 \mathrm{~mm} / \mathrm{h}, p<0.001$ ), CRP (median 6, IQR 2-48 mg/L versus median 1, IQR $1-5 \mathrm{mg} / \mathrm{L}, p<0.001$ ) and blood neutrophilic count (median 4.5 , IQR $1.6-14.6 \times 10^{3} / \mathrm{mm}^{3}$ versus median 3.4 , IQR $\left.1.4-5 \times 10^{3} / \mathrm{mm}^{3}, p<0.001\right)$.

Significant differences were found between Behcet's patients and controls as regards serum $\alpha$-defensins 1-3 (median 10.1, IQR 4-45 $\mu \mathrm{g} / \mathrm{ml}$ versus median 7.4 , IQR $0.6-13.2 \mu \mathrm{g} / \mathrm{ml}, p=0.001$ ), salivary $\alpha$-defensins $1-3$ (median 17.4, IQR $5.7-44 \mu \mathrm{g} / \mathrm{ml}$ versus median 8.6, IQR 3.3-11 $\mu \mathrm{g} / \mathrm{ml}, p<0.001$ ) and IL6 (median 16.4, IQR $2.9-40 \mathrm{pg} / \mathrm{ml}$ versus median 10.81 , IQR $5.4-16.2 \mathrm{pg} / \mathrm{ml}$, $p<0.001)$.

ROC curve for salivary and serum $\alpha$-defensins 1-3 was performed to discriminate between patients and controls. Performance characteristics and best cutoff values are shown in Fig. 1.

Table 1 shows that serum $\alpha$-defensins 1-3 more than the cutoff value was not significantly associated with age $(p<0.082)$ but was higher in the male gender $(p<$ $0.001)$. As regards to clinical manifestations, there were only significant associations between $\alpha$-defensins 1-3> cutoff value and oral ulcers $(p<0.001)$, arthritis $(p<$ $0.022)$ and panuveitis $(p=0.029)$. Higher Behcet's disease severity, activity and oral ulcer activity scores were found to be associated with serum $\alpha$-defensins $1-3>$ cutoff value $(p<0.001)$.

Table 2 shows significant associations between salivary $\alpha$-defensins 1-3 > cutoff value and oral ulcers $(p=$ 0.006). Salivary $\alpha$-defensins $1-3>$ cutoff value was significantly associated with Behcet's disease severity $(p<$ $0.001)$, activity $(p<0.001)$ and oral activity scores $(p=$ $0.006)$. However, salivary $\alpha$-defensins $1-3$ more than the 


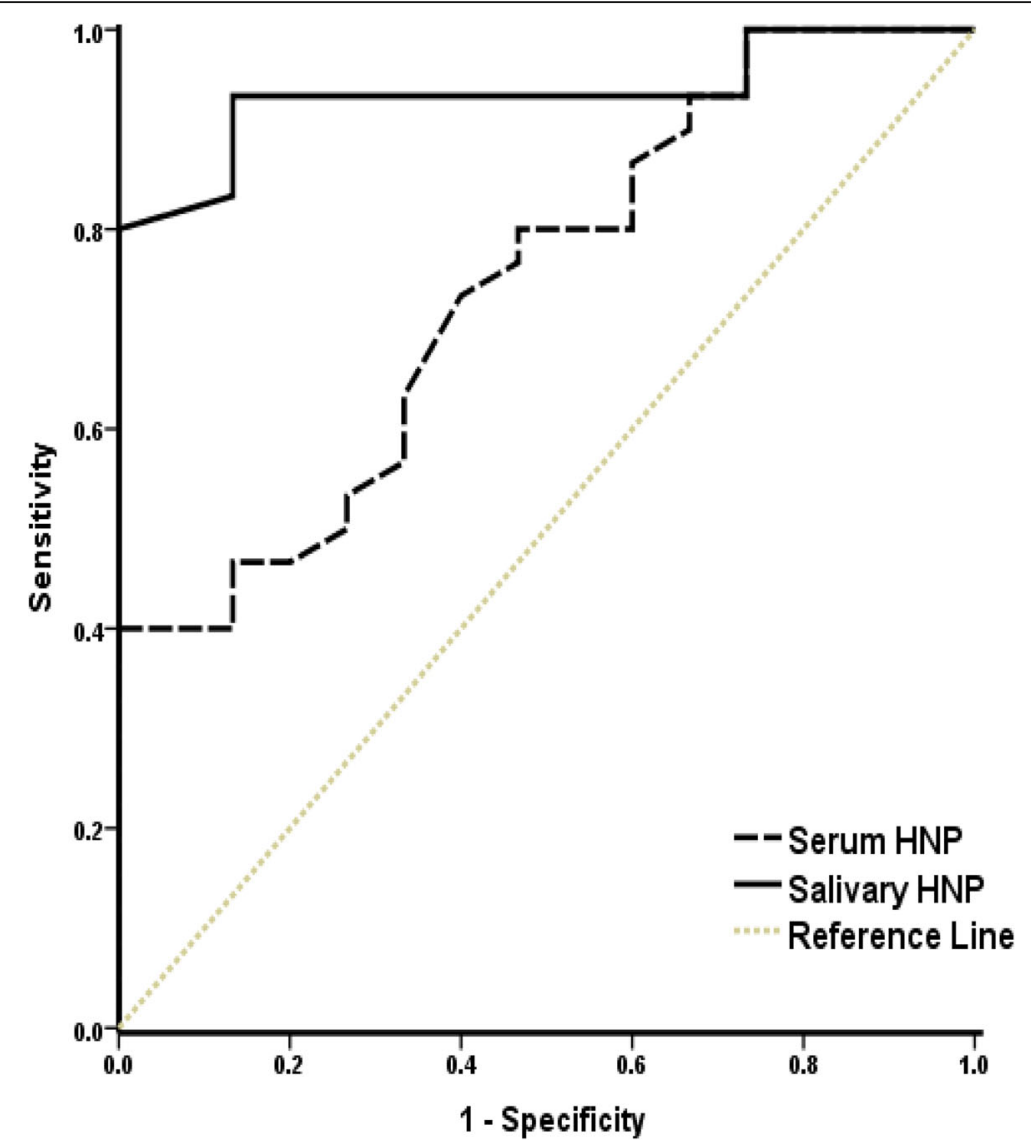

Fig. 1 Receiver operating Characterestic (ROC) analysis on utility of serum and salivary a defensins 1-3 for discrimination between cases and controls. Serum a-defensins 1-3 showed a fair area under the curve (AUC) $=0.743,95 \%$ confidence interval (CI) for the AUC (0.657-0.830) with sensitivity of $40 \%$ and specificity $100 \%$ at cutoff value of $17.3 \mu \mathrm{g} / \mathrm{ml}$, while salivary a-defensins $1-3$ showed excellent AUC $=0.936,95 \%$ Cl for the AUC (0.887-0.984) with sensitivity of $93.3 \%$ and specificity of $86.7 \%$ at cutoff value of $9.8 \mu \mathrm{g} / \mathrm{ml}$

cutoff value showed a statistically significant higher level of serum CRP $(p=0.017)$ and serum $\alpha$-defensins $1-3$ $(p=0.001)$.

\section{Discussion}

In the present study, the $\alpha$-defensins 1-3 serum level in $\mathrm{BD}$ patients was significantly higher than that in healthy controls. $\alpha$-Defensins 1-3 have a crucial role in the regulation of immunologic and inflammatory processes such as immature dendritic cell chemotaxis, cytotoxicity, complement activation, induction of cytokines and stimulation of cellular and humeral response [12]. The present study detected higher $\alpha$ defensins 1-3 salivary level in Behcet's patients as compared to controls. This can be explained by neutrophil migration via junctional epithelium surrounding the teeth to the oral cavity. In $\mathrm{BD}$, there are inflamed oral mucosa, increased oral ulceration and neutrophil overactivity which secrete a pathological amount of $\alpha$-defensins 1-3 [14].
Our results detected a significant correlation between $\alpha$-defensins 1-3 serum level and arthritis, panuveitis, BD severity and activity.

$\alpha$-Defensins induce the release of several cytokines such as IL-1, IL-8 and TNF- $\alpha$; IL-8 and other inflammatory cytokines such as TNF- $\alpha$ were found to increase in BD [12]. The essential role of IL-8 is neutrophil chemotaxis which is the main origin of $\alpha$-defensins $1-3$, and this makes a positive feedback circuit between $\alpha$ defensins and inflammatory cytokines, leading to a vicious cycle of inflammation in BD [21]. Several studies detected $\alpha$-defensin accumulation in synovial cavity of rheumatoid arthritis patients, and the defensin level in synovial fluid was correlated significantly with joint destruction and erosion [22]. Thus, it is assumed that $\alpha$ defensins may have a crucial role in aggravating or developing arthritis in $\mathrm{BD}$.

Joong et al. [23] detected that high copy numbers of the DEFA1 gene and the associated increase in $\alpha$ defensin-1 expression might initiate or increase the inflammatory response in the intestine of $\mathrm{BD}$ patients. 
Table 1 Comparison of demographic data, clinical symptoms, clinical scores and laboratory investigations according to serum adefensins 1-3 cutoff value

$\frac{\text { a-Defensins 1-3 }}{<\text { cutoff value, } N=36} \quad \frac{\text { a-Defensins } 1-3}{>\text { cutoff value, } N=24}$

\begin{tabular}{|c|c|c|c|c|c|}
\hline \multicolumn{6}{|l|}{ Demographic data } \\
\hline Age (years) (mean $\pm S D)$ & \multicolumn{2}{|c|}{$37.22 \pm 6.21$} & \multicolumn{2}{|c|}{$34.5 \pm 8.78$} & $<0.082$ \\
\hline Males, $n(\%)$ & 14 & $38.9 \%$ & 24 & $100 \%$ & $<0.001$ \\
\hline Females, $n$ (\%) & 22 & $61.1 \%$ & 0 & $0 \%$ & \\
\hline \multicolumn{6}{|l|}{ Clinical data } \\
\hline Genital ulcers, $\boldsymbol{n}(\%)$ & 8 & $22.2 \%$ & 8 & $33.3 \%$ & 0.340 \\
\hline Oral ulcers, $n(\%)$ & 18 & $50 \%$ & 24 & $100 \%$ & $<0.001$ \\
\hline DVT, $n$ (\%) & 6 & $16.7 \%$ & 6 & $25 \%$ & 0.517 \\
\hline Arthritis, $n$ (\%) & 0 & $0 \%$ & 4 & $16.7 \%$ & 0.022 \\
\hline Arthralgia, $n(\%)$ & 20 & $55.6 \%$ & 16 & $66.7 \%$ & 0.389 \\
\hline CNS, $n(\%)$ & 2 & $5.6 \%$ & 2 & $8.3 \%$ & 0.630 \\
\hline All uveitis, $n$ (\%) & 26 & $72.2 \%$ & 18 & $75 \%$ & 0.812 \\
\hline Anterior uveitis, $n$ (\%) & 4 & $11.1 \%$ & 6 & $25 \%$ & 0.178 \\
\hline Posterior uveitis, $n$ (\%) & 16 & $44.4 \%$ & 8 & $33.3 \%$ & 0.431 \\
\hline Panuveitis, $n$ (\%) & 6 & $16.7 \%$ & 4 & $16.7 \%$ & 0.029 \\
\hline \multicolumn{6}{|l|}{ Assessment scores } \\
\hline BD severity (median, IQR) & 13 & $9-13$ & 20.5 & $18-22$ & $<0.001$ \\
\hline BD activity (median, IQR) & 23 & $16-25.5$ & 38.5 & $34-41.25$ & $<0.001$ \\
\hline Oral ulcer score (median, IQR) & 3 & $0-4$ & 8 & $7-8.75$ & $<0.001$ \\
\hline \multicolumn{6}{|l|}{ Laboratory data } \\
\hline ESR 1st h (mm/h) & 28 & $13-35$ & 29 & $15.25-48.75$ & 0.565 \\
\hline ESR 2nd h $(\mathrm{mm} / \mathrm{h})$ & 40.5 & $30-70$ & 46.5 & 19-84.5 & 0.809 \\
\hline CRP (mg/dl) & 6 & $5-7$ & 7.5 & $5-20.25$ & 0.273 \\
\hline Blood neutrophils $\left(\times 10^{9} / \mathrm{L}\right)$ & 3.8 & $2.8-5.9$ & 5 & $3.275-6.925$ & 0.103 \\
\hline Salivary a-defensins $1-3(\mu \mathrm{g} / \mathrm{ml})$ & 14.5 & $10.8-15.4$ & 32.2 & $25.225-34.275$ & $<0.001$ \\
\hline IL6 (pg/ml) & 16.7 & $16.4-17$ & 15.05 & $10.3-23.75$ & 0.415 \\
\hline \multicolumn{6}{|l|}{ Drugs } \\
\hline Corticosteroid, $n(\%)$ & 26 & 72.2 & 22 & $91.7 \%$ & 0.100 \\
\hline Azathioprine, $n$ (\%) & 32 & $88.88 \%$ & 17 & $70.83 \%$ & 0.097 \\
\hline Colchicinee, $n$ (\%) & 18 & $50 \%$ & 12 & $50 \%$ & 1 \\
\hline Cyclosporine, $n$ (\%) & 6 & $16.66 \%$ & 8 & $33.33 \%$ & 0.212 \\
\hline Infliximab, $n$ (\%) & 8 & $22.22 \%$ & 8 & $33.33 \%$ & 0.558 \\
\hline Adalimumab, $n$ (\%) & 8 & $22.22 \%$ & 4 & $16.66 \%$ & 1 \\
\hline Mycophenolate, $n$ (\%) & 6 & $16.66 \%$ & 2 & $8.3 \%$ & 0.457 \\
\hline
\end{tabular}

$D V T$ deep vein thrombosis, CNS central nervous system, BD Behcet disease, ESR $1^{\text {st }} h, E S R 2^{\text {nd }} h$ erythrocyte sedimentation rate at the first and second hour, CRP Creactive protein, IL-6 interleukin 6

Accordingly, high DEFA1 gene copy numbers may be involved in the increased susceptibility to intestinal pathology in patients with BD.

Our results showed a positive significant correlation between $\alpha$-defensins 1-3 serum level with a number of oral ulcers, oral ulcer activity score and $\alpha$-defensins $1-3$ salivary level. Saliva is considered as an ultra-filtrate of the blood, and elevated neutrophil count in the blood may lead to elevated $\alpha$-defensins 1-3 salivary level [24]. The locally expressed or systemically secreted $\alpha$ defensins 1-3 act as chemical barriers in the protection of oral mucosa with innate immune response [25].

The release of pathological amount of $\alpha$-defensins 1-3 in saliva of BD patients from infiltrating neutrophils and 
Table 2 Comparison of demographic data, clinical symptoms, clinical scores and laboratory investigations according to salivary adefensins 1-3 cutoff value

$\frac{\text { Salivary a-defensins } 1-3}{<\text { cutoff value, } N=4} \quad \frac{\text { Salivary a-defensins } 1-3}{\text { > cutoff value, } N=56}$

\begin{tabular}{|c|c|c|c|c|c|}
\hline \multicolumn{6}{|l|}{ Demographic data } \\
\hline Age (years) (mean $\pm S D)$ & \multicolumn{2}{|c|}{$40 \pm 6.271$} & \multicolumn{2}{|c|}{$35.89 \pm 8.138$} & $<0.164$ \\
\hline Males, $n(\%)$ & 4 & 100 & 34 & 60.7 & 0.286 \\
\hline Females, $n(\%)$ & 0 & 0 & 22 & 39.3 & \\
\hline \multicolumn{6}{|l|}{ Clinical data } \\
\hline Genital ulcers, $n$ (\%) & 2 & 50 & 14 & 25 & 0.287 \\
\hline Oral ulcers, $n(\%)$ & 0 & 0 & 42 & 75 & 0.006 \\
\hline DVT, $n$ (\%) & 0 & 0 & 12 & 21.4 & 0.574 \\
\hline Arthritis, $n$ (\%) & 0 & 0 & 4 & 7.1 & 0.580 \\
\hline Arthralgia, $n(\%)$ & 1 & $25 \%$ & 22 & 39.28 & 0.57 \\
\hline CNS, $n(\%)$ & 0 & 0 & 4 & 7.1 & 0.573 \\
\hline All uveitis, $n$ (\%) & 4 & 100 & 40 & 71.4 & 0.565 \\
\hline Anterior uveitis, $n$ (\%) & 2 & 50 & 8 & 14.3 & 0.125 \\
\hline Posterior uveitis, $n(\%)$ & 2 & 50 & 22 & 39.3 & 0.626 \\
\hline Panuveitis, $n$ (\%) & 0 & 0 & 10 & 17.9 & 1 \\
\hline \multicolumn{6}{|l|}{ Assessment scores } \\
\hline BD severity (median, IQR) & 6.5 & $6-7$ & 15 & $13-19.5$ & 0.001 \\
\hline BD activity (median, IQR) & 12.5 & $12-13$ & 28.75 & $23-37.25$ & 0.001 \\
\hline Oral ulcer activity score (median, IQR) & 0 & $0-0$ & 5 & $3-7.75$ & 0.006 \\
\hline \multicolumn{6}{|l|}{ Laboratory data } \\
\hline ESR 1st h (mm/h) & 20.5 & $11-30$ & 28 & $13.5-48.75$ & 0.312 \\
\hline ESR 2nd h (mm/h) & 41.5 & $24-59$ & 45 & $28.5-85$ & 0.593 \\
\hline CRP $(\mathrm{mg} / \mathrm{dl})$ & 18 & $12-24$ & 18 & $6-48$ & 0.784 \\
\hline Blood neutrophils $\left(\times 10^{9} / \mathrm{L}\right)$ & 4.7 & $3.5-5.9$ & 4.35 & $2.825-6.325$ & 0.589 \\
\hline Serum a-defensins $1-3(\mu \mathrm{g} / \mathrm{ml})$ & 4 & $4-4$ & 10.5 & $7.9-28.75$ & 0.001 \\
\hline IL6 (pg/ml) & 16.7 & $16.4-17$ & 15.05 & $10.3-23.75$ & .812 \\
\hline \multicolumn{6}{|l|}{ Drugs } \\
\hline Corticosteroids, $n$ (\%) & 2 & $50 \%$ & 46 & $82.1 \%$ & 0.175 \\
\hline Azathioprine, $n$ (\%) & 0 & $0 \%$ & 26 & $46.4 \%$ & 0.126 \\
\hline Colchicinee, $n$ (\%) & 2 & $50 \%$ & 28 & $50 \%$ & 1 \\
\hline Cyclosporine, $n$ (\%) & 0 & $0 \%$ & 12 & $21.4 \%$ & 0.574 \\
\hline Infliximab, $n$ (\%) & 2 & $50 \%$ & 14 & $25 \%$ & 0.287 \\
\hline Adalimumab, $n$ (\%) & 2 & $50 \%$ & 7 & $12.5 \%$ & 0.103 \\
\hline Mycophenolate, $n$ (\%) & 2 & $50 \%$ & 6 & $10.71 \%$ & 0.082 \\
\hline
\end{tabular}

DVT deep vein thrombosis, CNS central nervous system, BD Behcet disease, ESR 1st $h, E S R$ 2nd $h$ erythrocyte sedimentation rate at first and second hour, CRP Creactive protein, IL-6 interleukin 6

those hyperactive and excessive neutrophils are blamable for increased oral ulcer activity and increased tissue damage [15].

We expected in our study that an increase in blood neutrophilic count and significant correlation between it and serum $\alpha$-defensins 1-3 could be present, but we found no statistically significant difference in blood neutrophilic count between patients and controls and also there was no significant correlation between $\alpha$ defensins 1-3 serum level and blood neutrophilic count. It seems that an increased serum level of $\alpha$-defensins 1-3 is due to increased $\alpha$-defensins 1-3 load in primary granules of neutrophils and increased neutrophil degranulation not due to increased number of neutrophils [26]. 
Elif Ugurel et al. [27] revealed that innate immunity is primarily involved in acute attacks of neuro-Behcet's disease (NBD) and treatment regimens attacking neutrophils might prove efficacy in the treatment of NBD and perhaps replace steroids that are already used for this disease.

In our results, serum and salivary $\alpha$-defensins $1-3$ levels were not significantly correlated with ESR and CRP; this goes with results of Katsantonis et al. [28], who found that ESR and CRP are not specific indicators for the process of inflammation and IL-8 is the most reliable indicator of disease activity and inflammation in Behcet's disease.

Serum and salivary $\alpha$-defensins $1-3$ were not significantly correlated with IL6; this could be explained by the study of Brook et al. [29] who found that $\alpha$ defensins 1-3 act as molecular brake on macrophagedriven inflammation and inhibit the release of multiple cytokines (TNF- $\alpha$, IL6, IL8 and IL1B) and are responsible for pathogen clearance and resolution of inflammation with minimal tissue damage; they prevent an excessive proinflammatory response that would create its own collateral damage while still acting as powerful antimicrobial peptides. This opens the way for developing similar peptide-based therapeutics that would act as effective combined antiinflammatory and antimicrobial agents.

This is the first study to measure both salivary and serum levels of $\alpha$-defensins 1-3 and to construct ROC curve for both to discriminate between cases and controls, and we found that salivary $\alpha$-defensins $1-3$ were more sensitive and had excellent AUC. Future studies are needed to clarify the role of alpha defensins in bridging between innate and cellular immunity by measuring different cytokines such as IL8, TNF and IL1B.

\section{Conclusion}

- Alpha defensins are highly involved in the pathogenesis of Behcet's disease since it is correlated with activity and severity of the disease and with oral ulcer activity. It could be used as a biological marker for the assessment of treatment response. Future studies are suggested to examine if it could be used as a future target for therapy in Behcet's disease.

- Salivary defensins are more sensitive and specific markers for the disease than serum defensins.

\section{Abbreviations}

AUC: Area under the curve; BD: Behcet's disease; BSAS: Behcet's Syndrome Activity Score; ESR: Erythrocyte sedimentation rate; IQR: Interquartile range; IL: Interleukins; ROC: Receiver operating characteristic; TNF: Tumour necrosis factor; WG: Wegener's granulomatosis

\section{Acknowledgements}

All authors wish to express great appreciations for all cooperative patients included in this study.

\begin{abstract}
Authors' contributions
RS., MA. and TE. were responsible for the idea, study design, patient selection, examination and assessment of disease activity and severity. SE. was responsible for the oral activity examination and assessment of activity of oral ulcers. ER. was responsible for the serum and salivary assessment of a-defensins 1-3. All authors were responsible for the interpretation of the statistical analysis and the results, writing, revising and approval of the final submitted manuscript.
\end{abstract}

\section{Funding}

This study had no funding from any resource.

\section{Availability of data and materials}

The datasets used and/or analysed during the current study are available from the corresponding author on reasonable request.

\section{Ethics approval and consent to participate}

The present study was conducted in agreement with the guidelines of the Declaration of Helsinki. This study was approved by the institutional research board of the Faculty of Medicine, Mansoura University, code (R/16.03.118) on 16 March 2018. A written informed consent was taken from all participants, according to the ethical standards of the institutional research board of Mansoura University.

\section{Consent for publication}

Not applicable

\section{Competing interests}

The authors declare that they have no competing interests.

\section{Author details}

${ }^{1}$ Rheumatology and Rehabilitation Department, Faculty of Medicine, Mansoura University, El Gomhoria street, Mansoura, Egypt. ${ }^{2}$ Oral Medicine and Periodontology Department, Faculty of Dentistry, Mansoura University, Mansoura, Egypt. ${ }^{3}$ Clinical Pathology Department, Faculty of Medicine, Mansoura University, Mansoura, Egypt. ${ }^{4}$ Internal Medicine Department, Faculty of Medicine, Mansoura University, Mansoura, Egypt.

Received: 2 April 2020 Accepted: 26 June 2020

Published online: 09 November 2020

\section{References}

1. Sakane T, Takeno M, Suzuki N, Inaba G (1999) Behcet's disease. N Engl J Med 341:1248-1291

2. Yazici H, Fresko I, Yurdakul S (2007) Behcet's syndrome: disease manifestations, management, and advances in treatment. Nat Clin Pract Rheumatol 3:148-155

3. Direskeneli H (2001) Behcet's disease: infectious aetiology, new autoantigens, and HLA-B51. Ann Rheum Dis 60:996-1002

4. Ganz T (2003) Defensins: antimicrobial peptides of innate immunity. Nat Rev Immunol 3:710-720

5. Ouellette AJ, Darmoul D, Tran D, Huttner KM, Yuan J, Selsted ME (1999) Peptide localization and gene structure of cryptdin 4, a differentially expressed mouse paneth cell alpha-defensin. Infect Immun 67(12):66436651 PMC 97078. PMID 10569786

6. Nassar H, Lavi E, Akkawi S, Bdeir K, Heyman SN, Raghunath PN, Tomaszewski J, Higazi AA (2007) alpha-Defensin: link between inflammation and atherosclerosis. Atherosclerosis. 194(2):452-457

7. Yang D, Biragyn A, Hoover DM, Lubkowski J, Oppenheim JJ (2004) Multiple roles of antimicrobial defensins, cathelicidins, and eosionphil-derived neurotoxin in host defence. Annu Rev Immunol 22:181-215

8. Vordenbäumen S, Fischer-Betz R, Timm D, Sander O, Chehab G, Richter J, Bleck E, Schneider M (2010) Elevated levels of human beta-defensin 2 (hbd2) and human neutrophil peptides (hnp) in systemic lupus erythematosus. Lupus 19(14):1648-1653 
9. Mukae H, Matsumoto N, Ashitani J, Mahimoto H, Kadota J, Nakazato M, Kohno S, Matsukura S (1996) Neutrophil-related cytokines and neutrophil products in bronchoalveolar lavage fluid. Eur Respir J 9:1950-1954

10. Tamiya H, Tani K, Miyata J, Sato K, Urata T, Lkhagvaa B, Otsuka S, Shigekiyo S, Sone S (2006) Defensin-and cathepsin G-ANCA in systemic lupus erythematosus. Rheumatol Int 27:147-152

11. Srivastava MD, Alexander F, Tuthill RJ (2005) Immunology of cutaneous vasculitis associated with both etanercept and infliximab. Scand J Immunol 61:329-336

12. Quinn K, Henriques M, Parker T, Slutsky AS, Zhang H (2008) Human neutrophil peptides: a novel potential mediator of inflammatory cardiovascular diseases. Am J Physiol Heart Circ Physiol 295:H1817-H1824

13. Becker K, Fitzgerald O, Green AJ, Keogan M, Newbury-Ecob R, Greenhalgh L et al (2009) Constitutional trisomy 8 and Behcet syndrome. Am J Med Genet A 149A:982

14. Mertens D, Gunaydin I, Fresko I, Yazici H, Mueller C (2004) Expression of alpha defensins HNP-1 in Behcet's disease: effector molecules of spontaneous and pathergy induced papulopustular lesions. Clin Exp Rheumatol 22(Suppl.34):93

15. Mumcu G, Cimilli H, Karacayli U, Inanc N, Ture-Ozdemir F, Eksioglu-Demiralp E et al (2012) Salivary levels of antimicrobial peptides Hnp1-3, LI-37 and S100 in Behcet's disease. Arch Oral Biol 57:642-646

16. Omma A, Sandikci SC, Colak S, Tecer D, Yucel C, Ozbalkan Z (2018) Serum calprotectin and ischemia modified albumin levels as markers of disease activity in Behçet's disease. Postepy Dermatol Alergol 35(6):609-613

17. International Team for the Revision of the International Criteria for Behcet's Disease (2014) The International Criteria for Behcet's Disease (ICBD): a collaborative study of 27 countries on the sensitivity and specificity of the new criteria. J Eur Acad Dermatol Venereol 28:338-347

18. Yilmaz S, Simsek I, Cinar M, Erdem H, Kose O, Yazici Y et al (2013) Patientdriven assessment of disease activity in Behcet's syndrome: cross-cultural adaptation, reliability and validity of the Turkish version of the Behcet's Syndrome Activity Score. Clin Exp Rheumatol 31:77-83

19. Krause I, Mader R, Sulkes J, Paul M, Uziel Y, Adawi M et al (2001) Behcet's disease in Israel: the influence of ethnic origin on disease expression and severity. J Rheumatol 28:1033-1036

20. Mumcu G, Sur H, Inanc N, Karacayli U, Cimilli H, Sisman N et al (2009) A composite index for determining the impact of oral ulcer activity in Behcet's disease and recurrent aphthous stomatitis. J Oral Pathol Med 38: 785-791

21. Ahn JK, Hwang J, Oh JM, Bae EK, Lee J, Lee YS et al (2011) Increased adefensin-1 expression in Korean patients with Behcet's disease. Joint Bone Spine 78:593-597

22. Bokarewa MI, Jin T, Tarkowski A (2003) Intraarticular release and accumulation of defensins and bactericidal/permeability-increasing protein in patients with rheumatoid arthritis. J Rheumatol 30:1719-1724

23. Ahn JK, Cha H-S, Lee J, Jeon CH, Koh E-M (2012) Correlation of DEFA1 gene copy number variation with intestinal involvement in Behcet's disease. J Korean Med Sci 27(1):107-109

24. Kucukkolbasi H, Kucukkolbasi S, Dursun R, Ayyildiz F, Kara H (2011) Determination of defensin HNP-1 in human saliva of patients with oral mucosal diseases. J Immunoass Immunochem 32:284-295

25. Gomes Pde S, Fernandes MH (2010) Defensins in the oral cavity: distribution and biological role. J Oral Pathol Med 39:1-9

26. Pay S, Simsek I, Erdem H, Dinc A (2007) Immunopathogenesis of Behcet's disease with special emphasize on the possible role of antigen presenting cells. Rheumatol Int 27:417-424

27. Ugurel E, Erdag E, Kucukali Cl, Olcay A, Sanli E et al (2019) Enhanced NLRP3 and DEFA1B expression during the active stage of parenchymal neuroBehçet's disease. In Vivo 33(5):1493-1497

28. Katsantonis J, Adler Y, Orfanos CE, Zouboulis CC (2000) AdamantiadesBehcet's disease: serum IL8 is a more reliable marker for disease activity than C-reactive protein and erythrocyte sedimentation rate. Dermatology 201:37-39

29. Brook M, Tomlinson GH, Miles K, Smith RW, Rossi AG, Hiemstra PS et al (2016) Neutrophil-derived alpha defensins control inflammation by inhibiting macrophage mRNA translation. Proc Nati Acad Sci USA 113:4350-4355

\section{Publisher's Note}

Springer Nature remains neutral with regard to jurisdictional claims in published maps and institutional affiliations.

\section{Submit your manuscript to a SpringerOpen ${ }^{\circ}$ journal and benefit from:}

- Convenient online submission

- Rigorous peer review

- Open access: articles freely available online

High visibility within the field

- Retaining the copyright to your article

Submit your next manuscript at $\boldsymbol{\nabla}$ springeropen.com 